\title{
The Effect of Discovery Teaching Style on Basic Techniques of Table Tennis Skills at SMP Semen Padang
}

\author{
Dessi Novita Sari ${ }^{(*)}$ \\ Faculty of Sport Science, Universitas Negeri Padang, Prof. Dr Hamka, Padang, Indonesia \\ "Corresponding author. Email: dessinovita10@fik.unp.ac.id
}

\begin{abstract}
This study aims to describe the improvement process on the basic techniques of table tennis skills using teaching styles and any related factors. The subjects were students of class VIII and IX amounted to 20 people. The sample was selected by using purposive sampling.The type of research used was quasi experiment. This study used quantitative approach. The basic techniques of table tennis skills consisting of three forms of tests; no spin forehand service measured by the test to the target table, forehand drive measured through a back board test, as well as backhand drive measured through a back board test. The results showed that discovery teaching style give significant effect to the basic techniques Table tennis skills for the students of SMP Semen Padang.
\end{abstract}

\section{Keywords: discovery teaching style, the basic techniques table tennis skills}

\section{INTRODUCTION}

The subjects of Physical Education, Sports, and Health (PJOK) play an important role in the world of education. Three aspects that must be possessed include: cognitive, affective and psychomotor aspects. In this case, so that the results of students become better, then the appropriate method is needed. The task of educators is to overcome the problems that arise so that they can get the right solution.

Lessons on Physical Education, Sports, and Health (PJOK) in the world of education require a balance between cognitive, affective and psychomotor aspects. Therefore, the skills of students will be even better if done in an appropriate and appropriate way. The application of the learning methods and models is adapted to the material taught such as command style, practice style, reciprocal style, self-evaluation style, inclusion style, discovery style, and so on. Of many PJOK materials in schools, there is a basic material for playing small balls, one of which is table tennis.

Based on information obtained from the selfdevelopment teacher of SMP Semen Padang that the number of students is 30 people, which can be categorized as having basic table tennis skills that are good there are 10 people, and the category of less than 20 people. In achieving these learning objectives, it is necessary to develop an integrated program that can be implemented outside of school hours.

Factors that influence come in terms of internal in the form of physical conditions of students, psychological aspects or factors that are directly related to the inner self of students, external factors can be in the form of lack of teachers' ability to modify sports equipment and facilities, lack a number of methods and models. Based on the description above, the authors are interested in observing and researching and discussing these issues, especially those related to the learning process of basic table tennis skills at SMP Semen Padang.

"Table tennis can be played with individuals or groups. Games with individuals are games that are played by one or single, while the group is a game that is played with a double or a team. Doubles are played with two people, both women and girls, men with men, and women with men called mixed doubles. One team consists of only 4 players" [1].

Table tennis can be divided into: grip / how to hold a bet, ready stance, strokes, and footwork / work legs. Various types of strokes / punches in table tennis games include service, drive, push, block, chop, counter hitting, topspin, drop shot, chopped smash, looped drive, and flick. In accordance with the variables to be studied, the researcher limits the variable skills of basic table tennis skills to service and drive. Service is a hitting technique to start the game by bouncing the ball first to the server table then crossing the net to the opponent's table[2].

The stages of no spin forehand services as below:

a. Beginning: left foot in front, right foot behind (for students with right hand, and vice versa for students with left hand). The body is dragging to the right more or less 45 degrees, the knee is bent.

b. Position: The service person must bounce the ball vertically without rotation, so that the ball rises at least $16 \mathrm{~cm}$ from the surface of the palm of the hand freely, 
then drops without anything before being hit using a bet. Bet pulled to the side of the back. Then the arm is swung to the front of the upper left by hitting the back of the ball. When the ball goes down, the service person hits it with the arm swinging to the front of the upper left by hitting the back of the ball so that it touches the table first then crosses the net to the receiving area.

c. Final stage: the end or further motion of the no spin forehand service is to stop at the top left side of the head and at this time the weight has been transferred to the front foot.

"The drive is the smallest blow friction"[3]. the stages or series of forehand drive movements as below [4]:

a. Beginning: Left foot in front, right foot behind (for students with right hand, while left-handed students are vice versa). The body pulls to the right of approximately 45 degrees, the knee is bent.

b. Position: Bet drawn to the back side. The head is facing toward the ground with your arms slightly down. Then the arm swings to the front of the upper left by swiping the back of the ball. In order for the ball to run in a curved motion over the net towards the opponent, the wrist helps swipe the ball upwards, until it stops at the left side above the head.

c. Final stage: The final attitude or continued movement of the forehand drive is to stop at the left side of the head and at this time the weight has been transferred to the front foot. below:

The stages or series of backhand drive movements as

a. Beginning: Right foot in front, left foot behind (for students with right hand, while left-handed students are vice versa). The body pulls to the left, the knee is bent.

b. Position: Bet drawn to the side of the body near the waist to the left. The head is facing toward the ground with your arms slightly down. Then the arm swings to the front of the upper right by swiping the back of the ball. In order for the ball to run in a curved motion over the net towards the opponent, the wrist helps swipe the ball upwards, until it stops in front of the top right.

c. Final stage: The final attitude or continued movement of the backhand drive is to stop in front of the upper right and at this time the weight has been moved to the front foot.

The teaching style in which the teacher's way of teaching can be distinguished from how the teacher treats and involves students in learning[5]. Teaching discovery styles are teaching materials sought and found by students themselves through various activities so that the teacher's tasks are more as facilitators and mentors for their students[6]. Teaching discovery style is a learning activity in which students try to find concepts for the material design provided by the teacher. At the time of evaluation, the teacher will provide comments on the activities carried out by students for improvement.

\section{METHODOLOGY}

This study used quasi experiment method. Quasi experiment is a way to find a causal relationship between two factors intentionally caused by the researcher. The research was conducted at SMP Semen Padang table tennis court. The time of the study lasted for 18 meetings, 16 treatments and 2 pre-test and post-test meetings. The technique that fits the situation in the self-development activities of table tennis on the sampling technique was purposive sampling. The sample was chosen based on consideration in the form of male sex and who were active in developing self-table tennis. The data of this study are the results of testing the basic skills of table tennis skills of SMP Semen Padang students. The test includes a service test in the form of a punch to the target set at the table, a back board test to measure forehand skills and a backhand drive.

\section{RESULTS AND DISCUSSION}

\subsection{Results}

\subsubsection{Pre Test Data}

Data on measurements of basic table tennis skills in this group consisting of 10 members $(n=10)$ highest score was 39 , lowest score was 27 , average score was 31 and standard deviation and 4. Pre Test frequency distribution Table tennis basic skills can be described in the following frequency distribution table:

Table 1. Distribution of Pre Test Data Skills of Basic techniques for table tennis Taight by Discovery Teaching Style.

\begin{tabular}{lll}
\hline Interval Class & fa & Fr $(\%)$ \\
\hline $27-29$ & 4 & 40 \\
$30-32$ & 4 & 40 \\
$33-35$ & 1 & 10 \\
$36-38$ & 0 & 0 \\
$39-41$ & 1 & 10 \\
Total & 10 & 100 \\
\hline
\end{tabular}

Based on the calculations listed in table 1, it can be seen that as many as 4 students $(40 \%)$ have basic table tennis skills at intervals of 27-29, and 4 students (40\%) have basic table tennis skills at intervals of $30-32,1$ student $(10 \%)$ has basic table tennis skills at intervals 33-35, and no students $(0 \%)$ have basic table tennis skills at intervals of 36-38 and 1 student $(10 \%)$ has technical skills table tennis base at intervals 39-41. Pre Test data can be seen in the histogram:

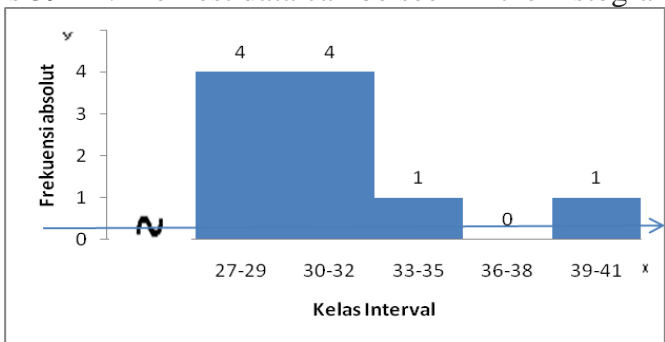

Figure 1. Histogram Data of Pre Test on Table Tennis Basic Skills Taught by Discovery Teaching Style.

From the description above, it can be stated from 10 sample people, who have a score above the average there are 2 people (20\%), who have scores in groups on average there are 4 people (40\%), and those who have scores below on average there are 4 people $(40 \%)$ 


\subsubsection{Post Test Data}

Data on the results of measuring table tennis basic engineering skills in this group consisting of 10 members ( $\mathrm{n}$ $=10$ ), highest score was 42 , lowest scores was 35 , average score was 37 and standard deviation was 2. Frequency distribution of post test table tennis basic skills can be described in the following frequency distribution table:

Table 2. Data Distribution of Post Test Table Tennis Basic Skills Discovery Teaching Style.

\begin{tabular}{|l|l|l|}
\hline Interval Class & fa & Fr (\%) \\
\hline $35-36$ & 4 & 40 \\
\hline $37-38$ & 3 & 30 \\
\hline $39-40$ & 2 & 20 \\
\hline $41-42$ & 1 & 10 \\
\hline Total & 10 & 100 \\
\hline
\end{tabular}

Based on the calculations shown in table 2, it can be seen that as many as 4 learners $(40 \%)$ have basic table tennis skills at intervals of 35-36, and 3 students (30\%) have basic table tennis skills at intervals $37-38,2$ students (20\%) have basic table tennis skills at intervals of 39-40, and 1 student (10\%) has basic table tennis technique skills at intervals 4142. Next, the description of the distribution of basic table tennis skills in the post test data above can be seen in the following histogram:

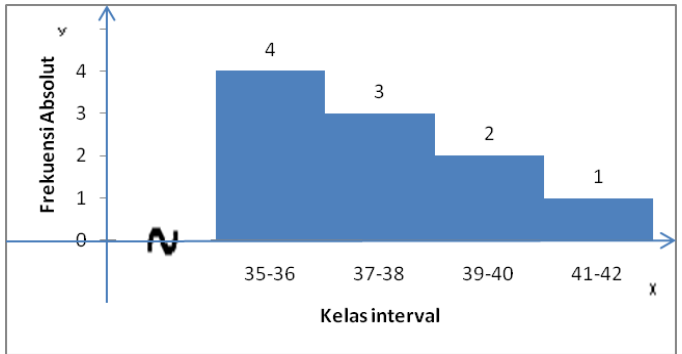

Figure 2. Histogram data of Post Test on Basic Skills of Table Tennis Taught by Discovery Teaching Style.

From the description above it can be explained from 10 sample people, who have a score above the average there are 3 people (30\%), who have scores in the group on average there are 3 people (30\%), and those who have scores below on average there are 4 people $(40 \%)$.

3.1.2 Test requirements analysis

The analysis requirements test is carried out using the normality test (liliefors test). Based on the test, it was obtained that Lo Pre test of 0.2478 and Ltabel at $\alpha 0.05$ and $\mathrm{N}=10$ of 0.2580 , Lo Post test of 0.1642 and Ltabel at $\alpha$ 0.05 and $\mathrm{N}=10$ at 0.2580 , thus Lo <Ltabel. It can be concluded that the data are normally distributed.

Table 3. Summary of Data Normality Test Results.

\begin{tabular}{lccccc}
\hline $\begin{array}{l}\text { Teaching } \\
\text { style }\end{array}$ & data & $\mathrm{n}$ & Lo & Lt & Conclusion \\
\hline Discovery & $\begin{array}{c}\text { Pre } \\
\text { test }\end{array}$ & 10 & 0.2478 & 0.2580 & Normal \\
& $\begin{array}{c}\text { Post } \\
\text { test }\end{array}$ & 10 & 0.1642 & 0.2580 & Normal \\
\hline
\end{tabular}

Based on the results of statistical analysis using the ttest, it is obtained as follows:

Table 4. Summary of t-Test Results at Discovery Teaching Style

\begin{tabular}{llll}
\hline Hypothesis & $\mathrm{T}_{\text {observed }}$ & $\mathrm{t}_{\text {table }}$ & note \\
\hline $\mathrm{n}=10$ & 4,94 & 2,26 & Ha: accepted \\
\hline
\end{tabular}

\section{DISCUSSION}

4.1 Effect of Teaching Style Discovery on Basic Table Tennis Skills

From the final test results of the teaching teaching discovery group, after being treated as many as 16 meetings, there was a significant increase of 4 to the basic skills of table tennis techniques. This is known from the initial test and the final test which is from the average score of 31 in the initial test to 35 in the final test.

The results of testing the second hypothesis shows that $\mathrm{t}_{\text {count }}$ is 4.94 while $\mathrm{t}$ table at $\alpha 0.05$ is 2.26 . So it can be concluded that $\mathrm{t}_{\text {count }} 4.94>\mathrm{t}$ table 2.26 means that the hypothesis proposed in this study can be accepted empirically

Teaching discovery style has a significant influence on basic table tennis skills in SMP Semen Padangstudents. In table tennis, every decision taken can be obtained from the experience of every move that is made. Teaching discovery style is teaching material sought and found by students through various activities so that the teacher's task is more as a facilitator and mentor for students. Teaching discovery style provides benefits in the form of developing intellectual potential, changing students from having external motivations into oneself, students will learn how to learn so students can be actively involved, maintain memory so that it lasts long because students are involved in the process of finding it.

\section{CONCLUSION}

Based on the results of data analysis that has been stated previously, it can be concluded that: The teaching style of discovery has a significant influence on the basic skills of table tennis students of SMP Semen Padang students calculated from $t_{\text {count }}(4.94)>t_{\text {table }}(2.26)$.

\section{REFERENCES}

[1] Simpson, Peter. "Teknik Bermain Pingpong". Bandung: Pionir Jaya. 1986, pp 36-40.

[2] Damiri, Ahmad dkk. "Olahraga Pilihan Tenis Meja”. Bandung: Depdikbud. 199, pp 25-30.

[3] Kertamanah, Alex. "Teknik dan Taktik Permainan Tenis Meja Dasar". Bandung: Raja Grafindo Persada. 2003, pp 54-58.

[4] Hodges, Larry. "Tenis Meja Tingkat Pemula". Jakarta: Raja Grafindo Persada. 1996, pp 14-34.

[5] Samsudin. "Pembelajaran Pendidikan Jasmani Olahraga dan Kesehatan SD/ MI". Jakarta: Litera. 2008, pp 23-30.

[6] Sanjaya, Wina. "Strategi Pembelajaran Berorientasi Standar Proses Pendidikan”. Jakarta: Kencana. 2006,pp 58-65. 